\title{
The role of human papillomaviruses in cancer progression
}

\author{
Pinar Tulay, Nedime Serakinci \\ Department of Medical Genetics, Faculty of Medicine, Near East University, 999058 Nicosia, Cyprus.
}

Correspondence to: Dr. Nedime Serakinci, Department of Medical Genetics, Faculty of Medicine, Near East University, 999058 Nicosia, Cyprus.

E-mail: nedimeserakinci@gmail.com

\section{A B S T R A C T}

The importance of human papillomavirus (HPV) infection and its role in the progress of cancer have been widely evaluated. The understanding of HPV association with certain cancers, such as cervical cancer, is very well established. A big step forward in the prevention of HPV associated cancers with the use of early detection by screening strategies has also been taken. In the last decade, development of HPV vaccination has reduced the number of cases in HPV infections and infection induced cancers. In this report, we review the HPV pathogenesis and highlight the mechanism of HPV involvement in cancer development.

Key words: Human papillomavirus; cancer; immune response; human papillomavirus vaccine

\section{INTRODUCTION}

Human papillomavirus (HPV) is considered to be one of the viral infections associated with cancers and other diseases worldwide. HPVs are non-enveloped viruses with double stranded circular DNA. ${ }^{[1,2]}$ The genome of papillomavirus constitutes three segments; early, late and genomic regions. The early region with E1, E2, E4-E8 forms half of the HPV genome. The early fragments function at different stages, in such both E1 and E2 is involved in the regulation of DNA replication, E2 in transcription (E2), E5, E6 and E7 in cell transformation [Table 1]. The late region $(\mathrm{L})$ with L1 and L2 forms $40 \%$ of the genome and the genomic regulatory region forms the rest of the genome. ${ }^{[3]}$ The late region of the genome involves the structural proteins of the virion [Table 1]..$^{[4]}$

HPVs are characterised according to their tissue tropism and they are subdivided into five main genera (Alpha-, beta-, gamma-, nu- and mu-papillomaviruses) depending on the DNA sequences, HPV life cycle characteristics and disease associations. ${ }^{[5-8]}$ Alpha-HPVs infect mucosal tissues, whereas beta-, gamma-, nu- and mu-papillomaviruses infects cutaneous sites causing cutaneous lesions in humans. ${ }^{[9,10]}$ However, as in recent years the number of HPV genotypes identified in healthy skin is increased, it is difficult to assign the cutaneous HPV types with a given

\begin{tabular}{|l|l|}
\hline \multicolumn{2}{|c|}{ Access this article online } \\
\hline Quick Response Code: & Website: \\
\hline & http://www.jcmtjournal.com \\
\cline { 2 - 3 } & \\
\hline
\end{tabular}

cutaneous pathology. The HPVs can be further subdivided according to the epidemiological classification as ones with low, intermediate and high risk oncogenic potentials depending on the viruses' ability to promote the proliferation of infected cells and lead to malignant transformations. ${ }^{[1,11]}$ The low risk HPVs including HPV6, 11, 42, 43 and 44 may cause condylomas and benign cervical lesions that do not form malignancies. ${ }^{[1,4,12,13]}$ The intermediate oncogenic risk HPVs involves HPV31, 33, 35, 51 and 52 and there is still an ongoing debate whether the intermediate oncogenic risk HPVs cause malignant transformation as much as the high risk HPV types. ${ }^{[2,14]}$ High oncogenic potential HPVs include HPV16, 18, 45 and 56 and these HPVs mostly cause neoplastic transformations. ${ }^{[2,4,14]}$ Unlike alphaHPVs, most of the beta- and gamma-HPVs results in asymptomatic infections in immune-competent individuals and these viruses adapt to their host and complete the lifecycle without causing any apparent diseases. ${ }^{[8,15-17]}$

Although the molecular defects caused by HPV infection leads to malignant transformation, it is not well established how they predispose to disease and whether keratinocyte ${ }^{[18,19]}$ or the immune system is being compromised. ${ }^{[20,21]}$ Therefore, although mainly the high risk HPV types cause malignant transformation and the low risks do no, it is possible that the low-risk viruses

This is an open access article distributed under the terms of the Creative Commons Attribution-NonCommercial-ShareAlike 3.0 License, which allows others to remix, tweak, and build upon the work non-commercially, as long as the author is credited and the new creations are licensed under the identical terms.

For reprints contact: service@oaepublish.com

How to cite this article: Tulay $P$, Serakinci $N$. The role of human papillomaviruses in cancer progression. J Cancer Metasta Treat 2016;2:201-13.

Received: 31-08-2015; Accepted: 17-03-2016. 


\begin{tabular}{|c|c|}
\hline $\begin{array}{l}\text { HPV } \\
\text { proteins }\end{array}$ & Function \\
\hline \multirow{3}{*}{ E1 } & Viral DNA replication \\
\hline & Repressive agent in transcription \\
\hline & Inhibition of DNA replication $^{[24,199]}$ \\
\hline \multirow{5}{*}{ E2 } & DNA replication \\
\hline & Functions with E1, especially in HPV6, 11 and $16^{[24]}$ \\
\hline & Responsible for coding proteins regulating viral DNA transcription ${ }^{[199]}$ \\
\hline & $\begin{array}{l}\text { cell transformation, initiating and inhibiting apoptosis, transcriptional regulation, and in the modulation of the } \\
\text { immortalizing and transformation poten-tial of } \mathrm{HPV}^{[24]}\end{array}$ \\
\hline & When inactive, it promotes E6 and E7 expression and influence tumor lesion development \\
\hline & When active, it inhibits E6 and E7 transciption leading to increased p53 expression and apoptosis of infected cells ${ }^{[199]}$ \\
\hline E4 & Affects the formation of the HPV-1 triggered nodules ${ }^{[24]}$ may be involved in the cell cycle regulation ${ }^{[199]}$ \\
\hline E5 & Transformation of viral DNA \\
\hline \multirow{3}{*}{ E6 } & $\begin{array}{l}\text { Miral DNA replication } \\
\text { Maintains the viral replication }\end{array}$ \\
\hline & Synthesis of the genes via epithelium differentiation ${ }^{[200]}$ \\
\hline & $\begin{array}{l}\text { Involved in HPV dependent malignant transformation via destructing the control of cell cycle regulation and cell } \\
\text { maturation }^{[199]}\end{array}$ \\
\hline \multirow{4}{*}{ E7 } & Maintains the viral replication \\
\hline & Contributes to the genetic instability of HPV-infected cells by interfering with the normal replication of centrosomes \\
\hline & Synthesis of the genes via epithelium differentiation ${ }^{[200]}$ \\
\hline & $\begin{array}{l}\text { Involved in HPV dependent malignant transformation via destructing the control of cell cycle regulation and cell } \\
\text { maturation }^{[199]}\end{array}$ \\
\hline
\end{tabular}

HPV: human papillomavirus

may also be associated with human cancers. The current understanding indicated that HPVs infect cells found in germ layers of the skin and mucous membranes, keranocyte or cells with differentiation potential of keranocyte. The mechanism of HPV infection is suspected to be similar among different tissues; in such the HPV infects the basal layer of the cervix causing exposure of the basement membrane, and HPV enters the basal layer of the tonsillar epithelium infecting and exposing the crypt cells. ${ }^{[22,23]}$

\section{TRANSMISSION OF HPV}

The most common sexually transmitted infection is presumed to be the HPV infection. HPV infection can be transmitted via both sexual and nonsexual contacts. HPVs penetrate the body through the skin and epidermis injuries, mucous membranes and skin abrasions. ${ }^{[24]}$ Genital types of HPVs are mostly transmitted sexually. Generally in women, epidemiological studies have shown that the HPV infection is associated with the number of sexual partners, initial age of sexual intercourse and the likelihood of one of the sexual partners with an HPV infection. ${ }^{[25,26]}$ Therefore for HPV associated cancers, such as cervical, penile or urethra, the sexual partner plays a key role as much as the individual's own sexual behaviour. ${ }^{[25,27]}$

More rarely, HPVs can be transmitted via perinatal transmission during birth from the mother to child that is also observed in the transmission of other microbial and viral infections. ${ }^{[28,29]}$ Horizontal transmission of HPV is also possible and it was first reported with a 5 year old boy of HPV2 infection presented as warts on the hands and anus of the child via genital-finger transmission. ${ }^{[30]}$

\section{IMMUNE RESPONSES TO HPV AND VACCINE-INDUCED PROTECTION}

HPVs that cause persistent visible papillomas, especially at oral and genital sites, are the main concern for the individuals. It is known that under some circumstances the virus is cleared and although the underlying mechanism of the virus clearance is not well understood, the immune response, particularly $\mathrm{T}$ cells, seems to play the main role. ${ }^{[31-33]}$ Lesion persistency and progression are increased in both animals and humans with genetic, iatrogenic or acquired cell mediated immune deficiencies, such as in patients with severe combined immunodeficiency, ${ }^{[34]}$ in immunosupressed organ recipient patients, ${ }^{[35]}$ in patients with epidermodysplasia verruciformis ${ }^{[35]}$ and sun-exposed sites of patients with non-melanoma skin cancer. ${ }^{[35-37]}$ Moreover, HPVs can escape the immune system and down regulate the innate immune signalling pathways. ${ }^{[38]}$

The clearance of high risk HPV types are believed to be harder since these types weaken the immune defences causing infection to continue and progress to neoplasias. However, it should be noted that progression from infections to cancer is a rare event and the first defence against HPV is the natural immunity. High risk HPV types are believed to destabilize the immune responses via obstructing the interferon pathway, down regulating major histocompatibility complex class I genes and changing the antigen production. ${ }^{\left[{ }^{39]}\right.}$ High risk HPV types continue to express the E6 and E7 oncoproteins that leads to genomic 
aberrations and malignancies. Furthermore, differences in cell tropism and disease progression patterns are believed to be one of the reasons of higher cancer association with certain HPV types, such as higher association of HPV18 with adenocarcinoma and in cervical intraepithelial neoplasias grade 2 (CIN2). The high risk HPV types causing adenocarcinomas may infect cells that already have a potential glandular differentiation. ${ }^{[40]}$ Therefore abortive or semipermissive infection of these cells may play an important role in the adenocarcinoma development. Recently, in silico models and epidemiological studies showed that the immune response may only contribute less than $20 \%$ of HPV clearance in individuals with normal immunity. ${ }^{[41]}$ Ryser and colleagues (2015) further proposed that the virus is mainly cleared by stem cell divisions in immunocompromised individuals. ${ }^{[41]}$

Overall balance between the positive and negative immune factors may vary and these may lead to clearance of lesions. Therefore, therapeutic vaccines against HPV infections may play a strong role in prevention HPV associated lesions and cancers. ${ }^{[42]}$ In 2006, the Food and Drug Administration approved the use of recombinant quadrivalent HPV vaccine gardasil for protection against HPV6, HPV11, HPV16 and HPV18 L1 proteins in females in the age between 9 and 26 years old. ${ }^{[43]}$ It is proposed that in three doses of this vaccination at 0,1 to 2 and 6 months, the HPV associated genital warts and the cervical cancer can be prevented. ${ }^{[44]}$ This vaccination is also proposed to protect against the vulvar and vaginal cancers as well as intraepithelial neoplasias. ${ }^{[45]}$ In 2009, the bivalent vaccine against HPV16 and HPV18 was licensed ${ }^{[46]}$ and this vaccine is intended to protect against anogenital warts, precancerous lesions and cervical cancer. ${ }^{[4]}$ Both the bivalent and quadrivalent HPV vaccines have been actively used in more than 80 countries. ${ }^{[47]}$ Both of the vaccines are shown to be safe, having enduring protection against primary infection and stable protection. ${ }^{[48]}$ These vaccines have a moderate cross-protection against high risk HPV types, HPV31, 33, 45, 52 and 58. ${ }^{[49,50]}$ However, only 70\% of cervical cancer cases can be avoided by using these vaccines. $^{[51]}$ Quadrivalent vaccines also protects against low risk HPV types, HPV6 and HPV 11 that causes 90\% of genital warts. ${ }^{[43]}$ The development of these vaccinations has brought a new era in the prevention of HPV and these vaccinations are great promise; however there is still room for much more development. In general, therapeutic vaccines have been proposed but only few of them reached clinical trials. The current vaccinations do not protect against all the HPV types and the cost of these vaccinations make them impossible to be used in some parts of the world, especially in newly developing countries. Therefore, although vaccinations enabled a tremendous step towards prevention of HPV associated diseases, more feasible and affordable vaccinations with protection against all the HPV types are required.

\section{GLOBAL BURDEN OF HPV IN CANCERS AND DISEASES: PREVALENCE AND ROLE OF HPV}

The highest HPV prevalence is observed to be $24 \%$ in Saharan Africa, 21\% in Eastern Europe and 16\% in Latin America. ${ }^{[52]}$ In majority of the populations, the highest prevalence of HPV is observed in women younger than 25 years. The prevalence reduces in older women with some having an increased rate in pri- or early-menopause. Although these prevalences are observed for many populations, in some others like China, the HPV prevalence is age-independent. On the other hand, HPV prevalence remains to be at a constant rate across all age groups in countries like Asia and Africa. ${ }^{[53]}$ The reason of different prevalences observed in different populations worldwide are not very well understood, but it is possible that it varies due to the age of initial sexual activity, the number of partners and the habits of the sexual activities.

Different HPV genera cause both non-cancerous and cancerous diseases. Formation of warts on the skin and uretra, mucous membranes of the oral cavity, respiratory tract, throat and genitals have been associated with HPV infections. Current data indicates that the prevalences of the genital HPV infections are considerably higher compared to the oral HPV. Globally HPV infections are associated with approximately $50 \%$ of HPV caused cancers in women and $5 \%$ in men. ${ }^{[54]}$ Different carcinogenesis is detected at different anatomical sites and at different level that is most likely because of the differences in the expression of the viral genome, in such HPV associated genital tract infections are observed at higher incidence compared to the head and neck cancer incidence. Genital HPV infections are connected with more than $99 \%$ of cervical cancers, ${ }^{[55]} 97 \%$ of anal cancer, ${ }^{[56]} 70 \%$ of vaginal cancers, ${ }^{[57]} 47 \%$ of penile cancers, ${ }^{[58]} 40 \%$ of vulval cancers, ${ }^{[57]} 47 \%$ of oropharynx cancers and $11 \%$ of oral cavity cancer cases. ${ }^{[59]}$

\section{ROLE OF HPV IN CANCER DEVELOPMENT}

The mechanism of cancer progression in patients with HPV infection is not well established. However, there are a number of hypothesis on the possible routes of HPV in cancer progression. One of the hypotheses suggests that the cancer progression is associated with the increased accessibility and proliferation of the basal layers at the metaplastic epithelial site and therefore this increases the risk of metastasis. This becomes even more apparent at the puberty time and the onset of sexual activity. ${ }^{[60]}$

The initial infection of the cell and the relation of this to the disease outcome are not well understood. Generally HPV infection causes cell destruction as well as cell transformation and tumour development. HPVs interfere with cell cycle regulation and prevent apoptosis in cells 
with unscheduled DNA replication. It is possible that HPV infection mainly affects the cells located near the squamocolumnar junctions that form the stratified epithelial layers of the transformation zone as the cervix matures, such as the epithelial reserve cells. ${ }^{[61,62]}$ It is believed that the formation of the lesion starts with the infection of the basal stem cell and the formation of a persistent lesion depends on the longevity of the stem cell. ${ }^{[6,63,64]}$ This hypothesis is especially convincing for the low-risk HPV types since they do not usually lead to neoplasia and do not particularly stimulate the basal cell proliferation. The viral replication proteins E1 and E2 may play a role in the amplification of the viral genome. ${ }^{[63,65,66]}$ One of the hypotheses suggests that E2 may be possibly involved in genome partitioning where the viral transcription is regulated by E2. ${ }^{[67]} \mathrm{A}$ viral DNA helicase, such as E1, may separate the viral DNA replication from cellular DNA replication during establishment and amplification of the genome. ${ }^{[6,68]}$ Of all the HPV proteins, E6 and E7 are the key ones associated in cancers via eliminating the tumour suppressors p53 and $\mathrm{Rb}$ leading to anti-apoptosis, genetic instability and formation of skin or mucosa lesions. ${ }^{[22,23,69]}$ In low-risk HPV types, the wound healing process may hold an important role in the initial proliferation of the infected cells. ${ }^{[70]}$ For the highrisk HPV types, viral proteins E6 and E7 function in the cell proliferation in the basal and parabasal cell layers. This function is particularly important at cervical sites where neoplasias may occur. ${ }^{[6]}$ The functions of viral proteins E6 and E7 vary between the high and low-risk HPV types and these are associated with different pathologies. ${ }^{[71]}$ The low risk HPV E6 and E7 proteins cause weak transformation or no transformation at all. RB1 is targeted and degraded by the high risk HPV E7 proteins, whereas E6 proteins target TP53 and stimulate telomerase (TERT). Telomerase activation is a fundamental stage for the high risk HPV type mediated cell immortalization in vitro. ${ }^{[72]}$ However, more studies involving animal models are required to understand the HPV integration in vivo. On the contrary, even though the low risk HPV E7 proteins bind to RB1, it is not involved in the degradation. Low risk E6 does not bind to TP53 and it does not stimulate TERT. ${ }^{[73]}$ The mechanism of oncogenesis associated with HPV is proposed to be through p16-INK4a expression. High risk HPV E7 triggers p16-INK4a through KDM6B histone demethylase causing p16-INK4a mediated CDK4/6 inhibition and RB1 mediated cell cycle arrest and senescence. ${ }^{[74-76]}$ More aberrations including abnormal number of centromeres, multipolar mitotic spindles, chromosome lagging and anaphase bridges are also observed in cells expressing HPV16 E6 and E7 genes. ${ }^{[77]}$ These aberrations may occur in cells with HPV infection at the early stages, but they can be easily detected in invasive cancers. Therefore, these abnormalities that originates during mitosis increases the risk of mutation accumulation that may cause malignant transformation in vitro. One of these aberrations is the allelic loss, such as losses in $3 p$ and $10 \mathrm{p}$ that are associated with telomerase activation.

\section{LOWER GENITAL TRACT NEOPLASIAS: CERVICAL, VAGINAL AND VULVAR CANCER}

Neoplasias of the genital tract includes cervical (CIN), vaginal and vulvar intraepithelial neoplasias and a fraction of these neoplasias progresses to invasive cancers. HPV infection is detected in almost all cervical, half of the vulvar and approximately $70 \%$ of vaginal tumors. ${ }^{[78]}$

The organisation of the life cycle of HPVs in the development of lower genital tract neoplasias is well established. ${ }^{[79-82]}$ Retrospective studies have reported that almost all the women with cervical cancers are infected with HPV and in the more severe cases, that are squamous cell carcinomas, HPV16 is the most prevalent type observed in $90 \%$ of the cases $^{[40,52,83,84]}$ Ten percent of the cervical cancers are adenocarcinomas that are mostly caused by HPV infections. ${ }^{[40]}$ Women with HPV16 (61\%) and HPV18 $(10 \%)$ were shown to have 200 fold higher risks for the development of cervical cancers. ${ }^{[1,85]}$ The prevalence of other HPV types are less observed in cervical cancer cases, in such HPV45 was observed in 6\%, HPV31 in 4\%, HPV52 in $3 \%$, HPV 35 in $2 \%$ and HPV 58 in $2 \%$ of cervical cancer cases. ${ }^{[86]}$

The risk factors for cervical cancers follow the similar parameters for the general HPV infection risks, such as high parity (more than 4 vaginal deliveries), full term pregnancy at earlier age (18 years old or earlier) and use of hormonal oral contraceptives. ${ }^{[83,87]}$ Progression of the cervical cancer can be affected by several factors including coinfection with other sexually transmitted infection, such as Chlamydia trachomatis, herpes simplex virus, HIV or tobacco smoking and immune suppression. ${ }^{[55,83]}$ Therefore, counselling adolescents at earlier age for avoiding tobacco use, initiation of sexual intercourse and limiting the number of partners may help to reduce the cervical cancer.

The HPV proteins E6 and E7 are proposed to play a role in the pathogenesis of HPV associated cervical cancers. ${ }^{[88]}$ The phenotype of the cervical neoplasia was suggested to vary depending on the expression levels of E6 and E7 were suggested to increase from cervical intraepithelial neoplasia grade 1 to 3 (CIN1 to CIN3). These interactions of HPV proteins with cellular pathways of the host cell will give a chance for potential targets for HPV based cancer treatment strategies. Additionally, E2 gene is also believed to take a part in cervical cancer since in about $35 \%$ of HPV induced cervical cancers full length viral genomes are expressed. ${ }^{[89,90]}$ The regulation of gene expression is changed when the viral DNA integrates with the cell chromosomes. This integration leads to a continuous expression of E6 and E7 proteins causing accumulation of mutations of the cellular DNA and promoting malignancies. ${ }^{[77,91]}$ These accumulations of mutations, mostly monosomies, trisomies, structural changes, chromatid gaps and breaks and double minutes, 
are often detected in cervical cancers as well as other epithelial tumors.

The underlying mechanism of the progression from CIN1 through CIN2, CIN3 and eventually cancer is not well established, it may be due to the early integration events in CIN1 or due to deregulation of viral gene expression. It is also possible that the initial deregulation leads to instability of chromosomes and causes integration. It is believed that the integration arises in high grade lesions, such as CIN2 and CIN3 and the deregulation of E6 and E7 expression may increase or remain at a constitute level. ${ }^{[92,93]}$ In this scheme, flat warts can be resembled in CIN1 lesions, however the proliferation level of the cell is lower in the basal and parabasal layers. ${ }^{[13]}$ Increased expression levels of E6 and E7 in high-risk HPV type infections causes CIN2+ phenotypes. This phenotype leads genetic changes that contribute to cancer progression. These suggest that low expression levels of E6 and E7 does not affect the function of the cellular targets in CIN1 and therefore does not contribute to cancer progression. In CIN2/ CIN3+, the viral deregulation assists the viral episome into the host cell chromosome. This may further cause deregulation of E6 and E7 expression. In clinical vaccine trials it was shown that young women can have CIN2+ soon after infection ${ }^{\text {[94-97] }}$ for these cases, it is possible that deregulation of the gene expression is due to cell signaling changes ${ }^{[98]}$ or epigenetic modifications, such as viral DNA methylation. ${ }^{[99]}$

An important step has been taken towards prevention of HPV induced cervical cancers with the use of vaccines against HPV. However, due to various reasons, including the unavailability of the vaccines in certain regions of the world or the high costs of the vaccines, the wide application of the vaccines is not available. Therefore, in case of cervical cancer development, early detection strategies and treatment play a vital role to prevent any deaths. The treatment for the early cervical cancers is usually performed by conisation or radical hysterectomy. For the more advanced tumors, cisplatin based chemo-radiotherapy is preferred that results in $65-80 \%$ survival rates. Surgical excisions are usually the standard for the HPV associated anogenital lesions. ${ }^{[100]}$ The treatment strategy for CIN is to eliminate the abnormal HPV infected precancerous cells and maintain the cervical integrity. One of the most commonly used treatments for CIN involves loop electrosurgical excision procedure, electrofulgaration and cryotherapy. ${ }^{[101]}$

The other lower genital cancers include vulvar and vaginal cancers. Majority of the vulvar and vaginal cancers are squamous cell carcinomas. ${ }^{[57]}$ In majority of the cancers of the vagina HPV DNA is detected; approximately half of the vaginal cancers are caused by HPV16 (54\%) followed by HPV18 (8\%). ${ }^{[57]}$ Similarly, HPV DNA is detected in most of the vulvar intraepithelial neoplasia, however only half of these neoplasias causes cancer. HPV16 is associated with $32 \%$ and HPV 18 with $4 \%$ of the cases. ${ }^{[57,102-104]}$ Therefore, although HPV may play a role in vulvar cancer, this association is not clear.

\section{BREAST CANCER}

Several epidemiological studies reported HPV detection in breast cancer samples. ${ }^{[105-109]}$ Nevertheless the role of HPV in breast carcinogenesis is by far not certain and further randomized control trials are required to establish the definite role of HPV in breast cancer development.

\section{HEAD AND NECK CARCINOMAS}

Head and neck carcinomas involve a wide range of tumors and is one of the most common cancers worldwide. ${ }^{[110]}$ The prevalence of HPV DNA in head and neck cancers depends on the cancer site, geography and ethnicity. ${ }^{[104]}$ The most consistent prevalence of HPV infection is the oropharyngeal cancers with an association of $35-50 \%$ in developed cancers, whereas the HPV is detected in approximately $5-15 \%$ within the rest of the oral cavity. ${ }^{[52,84]}$ The overall risk factors for head and neck carcinomas include tobacco smoking and alcohol consumption.

The first cases of HPV relationships with oral cell squamous cell carcinomas were reported in 2008 for lingual cancer, tonsil cancer and oropharyngeal cancers. ${ }^{[111,112]}$ Overall the prevalence of these cancers are higher in men compared to women. ${ }^{[113]}$ Oropharyngeal carcinomas (OPCs) are the most studied and the most characterised type of head and neck carcinomas. In the last decade the incidence of HPV related OPCs have doubled in number of patients and therefore more attention has drawn to these cancer types. ${ }^{[14]} \mathrm{HPV}$ positive oropharyngeal cancers are mainly associated with oral sex and rare p53 mutation. ${ }^{[115]}$ Interestingly HPV infection was shown to improve the prognosis of OPC with better survival is reported in HPV positive OPCs ${ }^{[116]}$ and therefore these patients may have a chance to benefit from a less intense treatment strategy. ${ }^{[117]}$ Chemotherapy using paclitaxel, cisplatin on centuximab; followed by concurrent radiation has been used in treatment of OPC patiens. ${ }^{[118]}$ With the increasing number of HPV associated OPC patients, the use of antiviral and immunotherapeutic strategies show an improved outcome. ${ }^{[42]}$ Although HPV related OPC have increased through the years, the HPV negative OPCs still account for the majority of the OPC patients.

The HPVs, mostly HPV16 and HPV33, were detected in quarter of the patients with invasive laryngeal cancers and are predominantly detected in women compared to men. ${ }^{[119-121]} \mathrm{HPV}$ is also associated with potential malignant disorders, such as erythroplakia, oral leukoplakia and oral lichen planus. ${ }^{[122]}$ Erythroplakia has the highest risk of malignant transformation. Half of the cases with erythroplakias alone is associated with HPV infection ${ }^{[123]}$ and the frequency of the HPV detection influences the severity of the lesions. In one study the HPV prevalence was $32.8 \%$ in oral lichen planus, $40.9 \%$ in oral leukoplakia 
and $47.7 \%$ in oral squamous cell carcinomas. ${ }^{[124]}$ Oral leukoplakia is associated with HPV6, HPV11 and HPV16 and these may lead to malignant oral diseases. ${ }^{[125-127]}$ Similarly, HPV is detected more often with increased prevalence in oral lichen planus. ${ }^{[128]}$

The overall prognosis of head and neck squamous cell carcinomas seems to be better with HPV infected patients. Young individuals appear to have increased risk of having HPV positive tonsillar and oropharyngeal carcinomas ${ }^{[129,130]}$ with better prognosis and lower relapse risks compared to HPV negative head and neck squamous cell carcinoma (HNSCC) patients. ${ }^{[131]}$ Approximately 6\% prevalence was reported for HPV positive OSCCs. ${ }^{[132]}$ However, more than half of the patients with HNSCC (57\%) were shown to have metastases to the brain where all are HPV positive. ${ }^{[133]}$

\section{LUNG CANCER}

Lung cancer is one the foremost causes of cancer associated deaths worldwide. Although cigarette smoking plays a crucial role in lung cancer development, less than $20 \%$ of the smokers have lung cancer. ${ }^{[134]}$ Therefore, other factors including inactivation of tumour suppressor genes, such as $\mathrm{p} 53, \mathrm{Rb}$ and $\mathrm{p} 16$, and HPV infection have been proposed to be involved in the development of lung carcinogenesis. ${ }^{[134,135]}$ The possible role of HPV in lung cancer was initially proposed due to the similarities of the morphological epithelial changes detected in bronchial carcinomas with genital HPV lesions. ${ }^{[136,137]} \mathrm{HPV}$ detection in lung cancer was confirmed in $1988^{[138]}$ and the association of HPV with lung cancer was then verified by detection of HPV DNA in lung cancer samples. ${ }^{[139,140]}$ However, the issue is debated and controversial studies have been reported. ${ }^{[141,142]}$ Some groups reported that E7 proteins of high risk HPV16 and HPV18 are detected, ${ }^{[143,144]}$ some reported that none of the HPV types are present in non-small lung cancer. ${ }^{[145]}$ An international pooled analysis of HPV association with lung cancers revealed that HPV DNA is present but in a very small number of lung tumors. ${ }^{[146]}$ Therefore, the direct relevance of lung cancer with HPV requires further analysis. A recent meta-analysis data showed that HPV infection has a strong relationship with lung cancer with significantly increased risk of lung squamous cell carcinoma upon HPV16 and HPV18 infection and in this meta-analysis, it is proposed that the HPV vaccination may lower the lung cancer risk. ${ }^{[147]}$

Respiratory papillomatosis (RRP) is a serious condition that may spread to lungs and can progress to cancer. ${ }^{[148,149]}$ Patients with RRP have an increased risk of developing laryngeal neoplasias and carcinomas. ${ }^{[150]}$ RRP is mainly caused by the alpha-HPVs, HPV6 and/or HPV11. ${ }^{[151]}$ The transmission of upper respiratory tract infections may be passed on by sexual contact and from mother to child during child birth canal. ${ }^{[4,152]}$ Although many therapies have applied for RRP patients, such as surgical, treatment with antivirals and chemotherapeutic drugs; there is limited success with mostly side effects. ${ }^{[153]}$ Therefore like all the other cancers, early detection and vaccines can play a crucial role in RRP. Although the present HPV vaccines protect against HPV 11 , there is the need for development of vaccines for other HPV types, especially HPV6 for the prevention of RRP.

\section{BLADDER CANCER}

The first association of HPV and bladder tumors was reported in 1988. ${ }^{[154]}$ The prevalence of HPV infection in bladder carcinomas ranges from $0 \%$ to $81 \% .^{[155-159]}$ Overall, the involvement of bladder cancer with HPV is controversial. Although some studies reported a positive correlation between HPV infection through contribution of E6 and E7 oncogenic proteins, ${ }^{[160-163]}$ some reported no association between HPV infected bladder carcinoma. ${ }^{[164,165]}$ Furthermore, p16-INK4a was reported to be involved in the development of bladder cancer through suppressing the inactivation of $\mathrm{Rb}$ protein association with HPV infected bladder carcinoma. ${ }^{[163,166,167]}$ The controversy continues with the inverted papiloma of the urinary tract and urothelial carcinomas. In some reports HPV is associated with inverted papilloma of the urinary bladder ${ }^{[168]}$ and urothelial carcinomas, ${ }^{[167,169]}$ but in the others no association was reported. ${ }^{[170,171]}$

HPVs, especially HPV16 and HPV18, were detected mostly in low grade (grade 1) tumours and never have they been reported for grade 3 carcinomas. ${ }^{[163,167,172-175]}$ Therefore potentially HPV is only associated with low grade carcinomas.

\section{PENILE CARCINOMA AND ANAL CARCINOMA}

Penile carcinomas mainly originate in the squamous mucosa of the glans, coronal sulcus or inner surface of the foreskin of the penile. Penile cancers are rare and they usually occur in uncircumcised men. ${ }^{[176]}$ About half (40-50\%) of the penile squamous cell carcinomas are related to the high risk HPV infection ${ }^{[52,177-180]}$ and mostly the basaloid and warty types of penile cancers are consistently related to HPV infection, whereas HPV DNA was only detected in some of the keratinizing and verrucous penile carcinomas. ${ }^{[179]}$ Mainly HPV16 (69\%) and HPV18 (13\%) play a role in the development of penile squamous cell carcinomas. ${ }^{[57]}$ High risk HPV types, generally HPV16 and HPV18, are detected in Bowenoid papulosis, which resemble genital warts but with high grade squamous cell carcinoma in situ, can be found on the external genitalia, perineum or perinally. ${ }^{[181]}$ HPV16 and HPV18 are also associated with Eryhtroplasia Queyrat, which is in situ carcinoma of the penile mucosa. This carcinoma can also be present on the urethra, vulva, tongue and oral mucosa. Buschke-Löwenstein tumors, which cause destruction of the underlying tissues leading to transformation into squamous cell carcinoma and are 
located on the penile glans, prepuce, vulva, vagina and perianal sites, are also associated with low risk HPVs, HPV6 and HPV 11. ${ }^{[182,183]}$ Additionally, in both males and females, approximately $85-95 \%$ of the anal cancers are HPV DNA positive. ${ }^{[52,104]}$ Of these, HPV16 (75\%) and HPV18 (3\%) are the causes for almost all the cases of anal cancers. ${ }^{[56,184]}$

\section{SKIN CANCER}

Similar to the head and neck, bladder and breast cancers, the involvement of HPV in cutaneous squamous cell carcinoma has not been surely established. A range of nonmelanoma skin cancer forms contain DNA from beta HPV types. ${ }^{[185]}$ HPV induced skin cancers include cutaneous squamous cell carcinoma and superficial squamous cell carcinoma, such as Bowen's disease. ${ }^{[186]}$ Approximately 30\% individuals with infection develop invasive squamous cell carcinomas with $90 \%$ of these tumors correlated with HPV5 and HPV8. ${ }^{[36,187]}$ Genetic susceptibility to HPV is demonstrated with epidermodysplasia verruciformis; however, HPV infection alone is not enough to develop cancerogenesis in epidermodysplasia verruciformis. ${ }^{[42]}$ Mainly, these tumors are induced by sun explosion and ultraviolet radiation. Cells with HPV5 and HPV8 E6 proteins disturb DNA double strand break repair ${ }^{[188]}$ and reduces the efficiency of base excision repair pathway ${ }^{[189]}$ causing higher sensitivity to UV-B exposure. It may be possible that because of impaired DNA repair activity, patients with acquired immunodeficiency syndrome or patients with epidermodysplasia verruciformis are more subjected for the infections and at a higher risk of developing HPV associated cutaneous malignancies. ${ }^{[185,190,191]}$ In order to reduce the prevalence of HPV induced skin cancers, diagnosis of skin manifestations caused by HPV should be routinely checked. ${ }^{[186]}$

\section{ROLE OF HPV IN NON-CANCEROUS DISEASES}

One of the most common non-oncogenic HPV diseases involves genital warts and the clinical manifestations extend from flat and common warts and cauliflower like or filiform warts. ${ }^{[186]}$ The genital warts are mostly common in younger people with the age of less than 25 years old and the transmission is more than $60 \%$ with an incubation time between 2 to 8 months. ${ }^{[192]}$ Various clinical presentations are observed when keratinocytes respond to the HPV infection depending on the HPV type and the anatomical site. Genital warts are mainly associated with HPV6 and HPV11. Although mainly low risk HPV types, HPV6 (89\%) and HPV11 (11\%), ${ }^{[193]}$ both high and low risk HPV types may cause genital warts. ${ }^{[194]}$ Bowenoid papulosis is described by several flat patches in genital area. Similarly, condylomata plana are flat warts that have been associated with HPV infection. ${ }^{[195]}$ Recurrence of genital warts with progression of lesions even after 3 months are reported in one-third of individuals with presence of genital warts. ${ }^{[196]}$
Genital warts can be found on penile shaft, base of the penis, scrotum, pubic region, glans and rectal area. In women, they are mostly present in the labia minora and vaginal opening. ${ }^{[197]}$ In the decision of the therapy strategy, many factors, such as morphology of the lesion, HPV classification and immune competent status, are taken into account. Unfortunately, none of the treatment strategies, including targeted lesion destruction or immunologic modification, are shown to clear the HPV infection or avoid the recurrence. With the use of HPV vaccines, the incidence of the warts has been decreased. ${ }^{[198]}$ If these warts remain untreated, they can either regresses spontaneously or they can grow larger and become more numerous resulting in complicated cases. ${ }^{[192]}$ Therefore, prevention HPV infection and therefore formation of these warts will be the optimum goal.

\section{CONCLUSION}

In the recent years, the biology of HPV infection and its role in the progress of cancer have been widely evaluated. All the data discussed in this review point out the significance of HPV infection in several benign and malignant diseases. Although the understanding of association of HPVs with cervical cancer is very well established further studies are required to analyse the relationships between HPV and certain cancers including breast, lung, bladder, some types of head and neck cancers and penile cancers.

To improve the mortality and morbidity of HPV associated cancers and diseases, there is an enormous need for early detection and prevention strategies. Although screening programs for early detection strategies have been developed for some cancers, such as cervical, there is still a big gap to be filled for other precancerous lesions, such as for some of the head and neck carcinomas. One of the examples of these screening strategies may involve oral examination, cytology and salivary HPV DNA tests which may provide a better early diagnosis for oral and oro-pharyngeal cancers. Moreover development and spread of more cost-effective vaccines is mandatory. Availability of low cost screening may prevent the future generations to develop HPVs induced cancers. In light of this knowledge, HPV vaccines are useful in the protection against cervical, oral and oropharyngeal cancers. However, it should be kept in mind that the current HPV vaccines do not protect against all HPV types, particularly beta-HPV types and their associated diseases. Therefore, despite all these advances, other strategies for early detection and prevention for different HPV types are required.

\section{Financial support and sponsorship}

Near East University, Center of Excellence research fund (www.neu.edu.tr).

\section{Conflicts of interest}

There are no conflicts of interest. 


\section{REFERENCES}

1. Munoz N, Bosch FX, de Sanjosé S, Herrero R, Castellsagué X, Shah $\mathrm{KV}$, Snijders PJ, Meijer CJ; International Agency for Research on Cancer Multicenter Cervical Cancer Study Group. Epidemiologic classification of human papillomavirus types associated with cervical cancer. N Engl J Med 2003;348:518-27.

2. Schiffman M, Clifford G, Buonaguro FM.Classification of weakly carcinogenic human papillomavirus types: addressing the limits of epidemiology at the borderline. Infect Agent Cancer 2009;4:8.

3. Hafkamp HC, Manni JJ, Speel EJ. Role of human papillomavirus in the development of head and neck squamous cell carcinomas. Acta Otolaryngol 2004;124:520-6.

4. Devaraj K, Gillison ML, Wu TC. Development of HPV vaccines for HPV-associated head and neck squamous cell carcinoma. Crit Rev Oral Biol Med 2003;14:345-62.

5. Bernard HU, Burk RD, Chen Z, van Doorslaer K, zur Hausen H, de Villiers EM.Classification of papillomaviruses (PVs) based on $189 \mathrm{PV}$ types and proposal of taxonomic amendments. Virology 2010;401:70-9.

6. Doorbar J. Molecular biology of human papillomavirus infection and cervical cancer. Clin Sci (Lond) 2006;110:525-41.

7. Bosch FX, Burchell AN, Schiffman M, Giuliano AR, de Sanjose S, Bruni L, Tortolero-Luna G, Kjaer SK, Muñoz N. Epidemiology and natural history of human papillomavirus infections and type-specific implications in cervical neoplasia. Vaccine 2008;26 Suppl 10:K1-16.

8. Ekström J, Bzhalava D, Svenback D, Forslund O, Dillner J. High throughput sequencing reveals diversity of Human Papillomaviruses in cutaneous lesions. Int $J$ Cancer 2011;129:2643-50.

9. de Villiers EM, Fauquet C, Broker TR, Bernard HU, zur Hausen H. Classification of papillomaviruses. Virology 2004;324:17-27.

10. Doorbar J, Quint W, Banks L, Bravo IG, Stoler M, Broker TR, Stanley MA. The biology and life-cycle of human papillomaviruses. Vaccine 2012;30 Suppl 5:F55-70.

11. zur Hausen H. Human papillomaviruses in the pathogenesis of anogenital cancer. Virology 1991;184:9-13.

12. Biedermann K, Dandachi N, Trattner M, Vogl G, Doppelmayr H, Moré E, Staudach A, Dietze O, Hauser-Kronberger C. Comparison of real-time PCR signal-amplified in situ hybridization and conventional PCR for detection and quantification of human papillomavirus in archival cervical cancer tissue. J Clin Microbiol 2004;42:3758-65.

13. Middleton K, Peh W, Southern S, Griffin H, Sotlar K, Nakahara T, El-Sherif A, Morris L, Seth R, Hibma M, Jenkins D, Lambert P, Coleman N, Doorbar J. Organization of human papillomavirus productive cycle during neoplastic progression provides a basis for selection of diagnostic markers. J Virol 2003;77:10186-201.

14. Cogliano V, Baan R, Straif K, Grosse Y, Secretan B, El Ghissassi F; WHO International Agency for Research on Cancer. Carcinogenicity of human papillomaviruses. Lancet Oncol 2005;6:204.

15. Nindl I, Gottschling M, Stockfleth E. Human papillomaviruses and non-melanoma skin cancer: basic virology and clinical manifestations. Dis Markers 2007;23:247-59.

16. Gottschling M, Göker M, Köhler A, Lehmann MD, Stockfleth E, Nindl I. Cutaneotropic human beta-/gamma-papillomaviruses are rarely shared between family members. J Invest Dermatol 2009; 129:2427-34.

17. Bottalico D, Chen Z, Dunne A, Ostoloza J, McKinney S, Sun C, Schlecht NF, Fatahzadeh M, Herrero R, Schiffman M, Burk RD. The oral cavity contains abundant known and novel human papillomaviruses from the Betapapillomavirus and Gammapapillomavirus genera. J Infect Dis 2011;204:787-92.

18. Chow KY1, Brotin É, Ben Khalifa Y, Carthagena L, Teissier S, Danckaert A, Galzi JL, Arenzana-Seisdedos F, Thierry F, Bachelerie F. A pivotal role for CXCL12 signaling in HPV-mediated transformation of keratinocytes: clues to understanding HPV- pathogenesis in WHIM syndrome. Cell Host Microbe 2010;8:523-33.

19. Lazarczyk M, Cassonnet P, Pons C, Jacob Y, Favre M. The EVER proteins as a natural barrier against papillomaviruses: a new insight into the pathogenesis of human papillomavirus infections. Microbiol Mol Biol Rev 2009;73:348-70.

20. Gulino AV. WHIM syndrome: a genetic disorder of leukocyte trafficking. Curr Opin Allergy Clin Immunol 2003;3:443-50.

21. Ortak T, Uysal AC, Alagoz MS, Orbay H, Sensoz O. Epidermodysplasia verruciformis: an unusual presentation. Dermatol Surg 2006; 32:302-6.

22. Woodman CB, Collins SI, Young LS. The natural history of cervical HPV infection: unresolved issues. Nat Rev Cancer 2007;7:11-22.

23. Howard JD, Chung CH. Biology of human papillomavirus-related oropharyngeal cancer. Semin Radiat Oncol 2012;22:187-93.

24. Beutner KR, Tyring S. Human papillomaviruses and human disease. Am J Med 1997;5: 9-15.

25. Kjaer SK, Chackerian B, van den Brule AJ, Svare EI, Paull G, Walbomers JM, Schiller JT, Bock JE, Sherman ME, Lowy DR, Meijer CL. High-risk human papillomavirus is sexually transmitted: evidence from a follow-up study of virgins starting sexual activity (intercourse). Cancer Epidemiol Biomarkers Prev 2001;10:101-6.

26. Castellsagué X, Ghaffari A, Daniel RW, Bosch FX, Muñoz N, Shah KV. Prevalence of penile human papillomavirus DNA in husbands of women with and without cervical neoplasia: a study in Spain and Colombia. J Infect Dis 1997;176:353-61.

27. Bosch FX, Castellsagué X, Muñoz N, de Sanjosé S, Ghaffari AM, González LC, Gili M, Izarzugaza I, Viladiu P, Navarro C, Vergara A, Ascunce N, Guerrero E, Shah KV. Male sexual behavior and human papillomavirus DNA: key risk factors for cervical cancer in Spain. $J$ Natl Cancer Inst 1996;88:1060-7.

28. Cason J. Perinatal acquisition of cervical cancer-associated papillomaviruses. Br J Obstet Gynaecol 1996;103:853-8.

29. Favre M, Majewski S, De Jesus N, Malejczyk M, Orth G, Jablonska S. A possible vertical transmission of human papillomavirus genotypes associated with epidermodysplasia verruciformis. J Invest Dermatol 1998;111:333-6

30. Bosch FX, YL Qiao, X Castellsagué. The epidemiology of human papillomavirus infection and its association with cervical cancer. Int J Gynecol Obstet 2006;94:S8-21.

31. Stern PL, MH Einstein. From HPV infection to oncogenesis: a brief review of the complex immunobiological events. Curr Cancer Ther Rev 2010: 110-6.

32. van der Burg SH, Melief CJ. Melief, Therapeutic vaccination against human papilloma virus induced malignancies. Curr Opin Immunol 2011;23:252-7

33. Hanahan D, Weinberg RA. Hallmarks of cancer: the next generation. Cell 2011;144:646-74.

34. Laffort C, Le Deist F, Favre M, Caillat-Zucman S, Radford-Weiss I, Debré M, Fraitag S, Blanche S, Cavazzana-Calvo M, de Saint Basile G, de Villartay JP, Giliani S, Orth G, Casanova JL, Bodemer C, Fischer A. Severe cutaneous papillomavirus disease after haemopoietic stem-cell transplantation in patients with severe combined immune deficiency caused by common gammac cytokine receptor subunit or JAK-3 deficiency. Lancet 2004;363:2051-4.

35. Gewirtzman A, Bartlett B, Tyring S. Epidermodysplasia verruciformis and human papilloma virus. Curr Opin Infect Dis 2008;21:141-6.

36. Dubina M, Goldenberg G. Viral-associated nonmelanoma skin cancers: a review. Am J Dermatopathol 2009;31:561-73.

37. Weissenborn S, Neale RE, Waterboer T, Abeni D, Bavinck JN, Green AC, Harwood CA, Euvrard S, Feltkamp MC, de Koning MN, Naldi L, Quint WG, Tessari G, Proby CM, Wieland U, Pfister H; EPI-HPVUV-CA group. Beta-papillomavirus DNA loads in hair follicles of immunocompetent people and organ transplant recipients. Med Microbiol Immunol 2012;201:117-25.

38. Kanodia S, Fahey LM, Kast WM. Mechanisms used by human 
papillomaviruses to escape the host immune response. Curr Cancer Drug Targets 2007;7:79-89.

39. O’Brien PM, Saveria Campo M. Evasion of host immunity direct by papillomavirus-encoded proteins. Virus Res 2002;88:103-17.

40. de Sanjose S, Quint WG, Alemany L, Geraets DT, Klaustermeier JE, Lloveras B, Tous S, Felix A, Bravo LE, Shin HR, Vallejos CS, de Ruiz PA, Lima MA, Guimera N, Clavero O, Alejo M, LlombartBosch A, Cheng-Yang C, Tatti SA, Kasamatsu E, Iljazovic E, Odida M, Prado R, Seoud M, Grce M, Usubutun A, Jain A, Suarez GA, Lombardi LE, Banjo A, Menéndez C, Domingo EJ, Velasco J, Nessa A, Chichareon SC, Qiao YL, Lerma E, Garland SM, Sasagawa T, Ferrera A, Hammouda D, Mariani L, Pelayo A, Steiner I, Oliva E, Meijer CJ, Al-Jassar WF, Cruz E, Wright TC, Puras A, Llave CL, Tzardi M, Agorastos T, Garcia-Barriola V, Clavel C, Ordi J, Andújar M, Castellsagué X, Sánchez GI, Nowakowski AM, Bornstein J, Muñoz N, Bosch FX; Retrospective International Survey and HPV Time Trends Study Group. Human papillomavirus genotype attribution in invasive cervical cancer: a retrospective cross-sectional worldwide study. Lancet Oncol 2010;11:1048-56.

41. Ryser MD, Myers ER, Durrett R. HPV Clearance and the Neglected Role of Stochasticity. PLoS Comput Biol 2015;11:e1004113.

42. Stern PL, van der Burg SH, Hampson IN, Broker TR, Fiander A, Lacey CJ, Kitchener HC, Einstein MH. Therapy of human papillomavirus-related disease. Vaccine 2012;30 Suppl 5:F71-82.

43. Future II Study Group. Quadrivalent vaccine against human papillomavirus to prevent high-grade cervical lesions. $N$ Engl J Med 2007;356:1915-27.

44. Garland SM, Hernandez-Avila M, Wheeler CM, Perez G, Harper DM, Leodolter S, Tang GW, Ferris DG, Steben M, Bryan J, Taddeo FJ, Railkar R, Esser MT, Sings HL, Nelson M, Boslego J, Sattler C, Barr E, Koutsky LA; Females United to Unilaterally Reduce Endo/Ectocervical Disease (FUTURE) I Investigators. Quadrivalent vaccine against human papillomavirus to prevent anogenital diseases. N Engl J Med 2007; 356:1928-43.

45. Choi YH, Chapman R, Gay N, Jit M. Potential overestimation of HPV vaccine impact due to unmasking of non-vaccine types: quantification using a multi-type mathematical model. Vaccine 2012;30:3383-8.

46. Wheeler CM, Kjaer SK, Sigurdsson K, Iversen OE, Hernandez-Avila M, Perez G, Brown DR, Koutsky LA, Tay EH, García P, Ault KA, Garland SM, Leodolter S, Olsson SE, Tang GW, Ferris DG, Paavonen J, Steben M, Bosch FX, Dillner J, Joura EA, Kurman RJ, Majewski S, Muñoz N, Myers ER, Villa LL, Taddeo FJ, Roberts C, Tadesse A, Bryan J, Lupinacci LC, Giacoletti KE, James M, Vuocolo S, Hesley TM, Barr E. The impact of quadrivalent human papillomavirus (HPV; types 6, 11, 16, and 18) L1 virus-like particle vaccine on infection and disease due to oncogenic nonvaccine HPV types in sexually active women aged 16-26 years. J Infect Dis 2009;199:936-44.

47. Aggarwal P. Cervical cancer: Can it be prevented? World J Clin Oncol 2014;5:775-80.

48. Schiller JT, Castellsagué X, Garland SM. A review of clinical trials of human papillomavirus prophylactic vaccines. Vaccine 2012;30 Suppl 5:F123-38.

49. Donovan B, Franklin N, Guy R, Grulich AE, Regan DG, Ali H, Wand H, Fairley CK. Quadrivalent human papillomavirus vaccination and trends in genital warts in Australia: analysis of national sentinel surveillance data. Lancet Infect Dis 2011;11:39-44.

50. Future II Study Group. Quadrivalent vaccine against human papillomavirus to prevent high-grade cervical lesions. $N$ Engl J Med 2007;356:1915-27.

51. Kjær SK, Frederiksen K, Munk C, Iftner T. Long-term absolute risk of cervical intraepithelial neoplasia grade 3 or worse following human papillomavirus infection: role of persistence. $J$ Natl Cancer Inst 2010;102:1478-88.

52. Forman D, de Martel C, Lacey CJ, Soerjomataram I, Lortet-Tieulent
J, Bruni L, Vignat J, Ferlay J, Bray F, Plummer M, Franceschi S. Global burden of human papillomavirus and related diseases. Vaccine 2012;30 Suppl 5:F12-23.

53. de Sanjosé S. Human Papillomavirus and cancer. Epidemiology and prevention. 4th monograph of the Spanish Society of Epidemiology. Barcelona, Spain: Spanish Society of Epidemiology; 2006. p. 143-7.

54. zur Hausen H. Papillomaviruses in the causation of human cancers - a brief historical account. Virology 2009;384:260-5.

55. Walboomers JM, Jacobs MV, Manos MM, Bosch FX, Kummer JA, Shah KV, Snijders PJ, Peto J, Meijer CJ, Muñoz N. Human papillomavirus is a necessary cause of invasive cervical cancer worldwide. J Pathol 1999;189:12-9.

56. Abramowitz L, Jacquard AC, Jaroud F, Haesebaert J, Siproudhis L, Pradat P, Aynaud O, Leocmach Y, Soubeyrand B, Dachez R, Riethmuller D, Mougin C, Pretet JL, Denis F. Human papillomavirus genotype distribution in anal cancer in France: the EDiTH V study. Int J Cancer 2011;129: 433-9.

57. De Vuyst H, Clifford GM, Nascimento MC, Madeleine MM, Franceschi S. Prevalence and type distribution of human papillomavirus in carcinoma and intraepithelial neoplasia of the vulva, vagina and anus: a meta-analysis. Int J Cancer 2009;124:1626-36.

58. Miralles-Guri C, Bruni L, Cubilla AL, Castellsagué X, Bosch FX, de Sanjosé S. Human papillomavirus prevalence and type distribution in penile carcinoma. J Clin Pathol 2009;62:870-8.

59. St Guily JL, Jacquard AC, Prétet JL, Haesebaert J, Beby-Defaux A, Clavel C, Agius G, Birembaut P, Okaïs C, Léocmach Y, Soubeyrand B, Pradat P, Riethmuller D, Mougin C, Denis F. Human papillomavirus genotype distribution in oropharynx and oral cavity cancer in France-The EDiTH VI study. J Clin Virol 2011;51:100-4.

60. Grayson W, Rhemtula HA, Taylor LF, Allard U, Tiltman AJ. Detection of human papillomavirus in large cell neuroendocrine carcinoma of the uterine cervix: a study of 12 cases. J Clin Pathol 2002;55:108-14.

61. Gravitt PE, Lacey JV Jr, Brinton LA, Barnes WA, Kornegay JR, Greenberg MD, Greene SM, Hadjimichael OC, McGowan L, Mortel R, Schwartz PE, Zaino R, Hildesheim A. Evaluation of self-collected cervicovaginal cell samples for human papillomavirus testing by polymerase chain reaction. Cancer Epidemiol Biomarkers Prev 2001;10:95-100.

62. Bouvard V, Baan RA, Grosse Y, Lauby-Secretan B, El Ghissassi F, Benbrahim-Tallaa L, Guha N, Straif K; WHO International Agency for Research on Cancer Monograph Working Group. Carcinogenicity of malaria and of some polyomaviruses. Lancet Oncol 2012;13:339-40.

63. Egawa K. Do human papillomaviruses target epidermal stem cells? Dermatology 2003;207: 251-4.

64. Schmitt A, Rochat A, Zeltner R, Borenstein L, Barrandon Y, Wettstein FO, Iftner $\mathrm{T}$. The primary target cells of the high-risk cottontail rabbit papillomavirus colocalize with hair follicle stem cells. J Virol 1996;70:1912-22.

65. Kim K, Lambert PF. E1 protein of bovine papillomavirus 1 is not required for the maintenance of viral plasmid DNA replication. Virology 2002;293:10-4

66. Angeletti PC, Kim K, Fernandes FJ, Lambert PF. Stable replication of papillomavirus genomes in Saccharomyces cerevisiae. $J$ Virol 2002;76:3350-8.

67. McBride AA. Replication and partitioning of papillomavirus genomes. Adv Virus Res 2008;72:155-205.

68. Blakaj DM, Fernandez-Fuentes N, Chen Z, Hegde R, Fiser A, Burk RD, Brenowitz M. Evolutionary and biophysical relationships among the papillomavirus E2 proteins. Front Biosci (Landmark Ed) 2009; 14:900-17.

69. Chung $\mathrm{CH}$, Gillison ML. Human papillomavirus in head and neck cancer: its role in pathogenesis and clinical implications. Clin Cancer Res 2009; 15:6758-62.

70. Valencia C, Bonilla-Delgado J, Oktaba K, Ocádiz-Delgado R, Gariglio P, Covarrubias L. Human papillomavirus E6/E7 
oncogenes promote mouse ear regeneration by increasing the rate of wound re-epithelization and epidermal growth. J Invest Dermatol 2008;128:2894-903

71. Klingelhutz AJ, Roman A. Cellular transformation by human papillomaviruses: lessons learned by comparing high- and low-risk viruses. Virology 2012;424:77-98.

72. von Knebel Doeberitz M. New markers for cervical dysplasia to visualise the genomic chaos created by aberrant oncogenic papillomavirus infections. Eur J Cancer 2002;38:2229-42.

73. Moody CA, Laimins LA. Human papillomavirus oncoproteins: pathways to transformation. Nat Rev Cancer 2010;10:550-60.

74. Agger K, Cloos PA, Rudkjaer L, Williams K, Andersen G, Christensen J, Helin K. The H3K27me3 demethylase JMJD3 contributes to the activation of the INK4A-ARF locus in response to oncogene- and stress-induced senescence. Genes Dev 2009;23:1171-6.

75. Barradas M, Anderton E, Acosta JC, Li S, Banito A, RodriguezNiedenführ M, Maertens G, Banck M, Zhou MM, Walsh MJ, Peters G, Gil J. Histone demethylase JMJD3 contributes to epigenetic control of INK4a/ARF by oncogenic RAS. Genes Dev 2009;23:1177-82.

76. Gonzalez SL, Stremlau M, He X, Basile JR, Münger K. Degradation of the retinoblastoma tumor suppressor by the human papillomavirus type 16 E7 oncoprotein is important for functional inactivation and is separable from proteasomal degradation of E7. J Virol 2001;75:7583-91

77. Duensing S, Münger K. Mechanisms of genomic instability in human cancer: insights from studies with human papillomavirus oncoproteins. Int J Cancer 2004;109:157-62.

78. Lowy DR, Schiller JT. Reducing HPV-associated cancer globally. Cancer Prev Res (Phila) 2012;5:18-23.

79. Wikström A, Hedblad MA, Syrjänen S. Penile intraepithelial neoplasia: histopathological evaluation, HPV typing, clinical presentation and treatment. J Eur Acad Dermatol Venereol 2012;26:325-30.

80. Silva RJ, Casseb J, Andreoli MA, Villa LL. Persistence and clearance of HPV from the penis of men infected and non-infected with HIV. $J$ Med Virol 2011;83:127-31

81. Szentirmay Z, Pólus K, Tamás L, Szentkuti G, Kurcsics J, Csernák E, Tóth E, Kásler M. Human papillomavirus in head and neck cancer: molecular biology and clinicopathological correlations. Cancer Metastasis Rev 2005;24:19-34.

82. Syrjänen K, Syrjänen S, Lamberg M, Pyrhönen S, Nuutinen J. Morphological and immunohistochemical evidence suggesting human papillomavirus (HPV) involvement in oral squamous cell carcinogenesis. Int J Oral Surg 1983;12:418-24.

83. Harper DM, Demars LR. Primary strategies for HPV infection and cervical cancer prevention. Clin Obstet Gynecol 2014;57:256-78.

84. Bosch FX, Broker TR, Forman D, Moscicki AB, Gillison ML, Doorbar J, Stern PL, Stanley M, Arbyn M, Poljak M, Cuzick J, Castle PE, Schiller JT, Markowitz LE, Fisher WA, Canfell K, Denny LA, Franco EL, Steben M, Kane MA, Schiffman M, Meijer CJ, Sankaranarayanan R, Castellsagué X, Kim JJ, Brotons M,Alemany L, Albero G, Diaz M, de Sanjosé S. Comprehensive control of human papillomavirus infections and related diseases. Vaccine 2013;31 Suppl 8:I1-31

85. Bosch FX, Lorincz A, Muñoz N, Meijer CJ, Shah KV. The causal relation between human papillomavirus and cervical cancer. $J$ Clin Pathol 2002;55:244-65.

86. Schiffman M, Kjaer SK. Chapter 2: Natural history of anogenital human papillomavirus infection and neoplasia. J Natl Cancer Inst Monogr 2003:14-9.

87. Wen LM, Estcourt CS, Simpson JM, Mindel A. Risk factors for the acquisition of genital warts: are condoms protective? Sex Transm Infect 1999;75:312-6.

88. Münger K, Howley PM. Human papillomavirus immortalization and transformation functions. Virus Res 2002;89:213-28.

89. Klaes R, Woerner SM, Ridder R, Wentzensen N, Duerst M, Schneider
A, Lotz B, Melsheimer P, von Knebel Doeberitz M. Detection of high-risk cervical intraepithelial neoplasia and cervical cancer by amplification of transcripts derived from integrated papillomavirus oncogenes. Cancer Res 1999;59:6132-6.

90. Li K, Jin X, Fang Y, Wang C, Gong M, Chen P, Liu J, Deng D, Ai J. Correlation between physical status of human papilloma virus and cervical carcinogenesis. J Huazhong Univ Sci Technol Med Sci 2012;32:97-102.

91. Baseman JG, Koutsky LA. The epidemiology of human papillomavirus infections. J Clin Virol 2005;32 Suppl 1:S16-24.

92. Melsheimer P, Vinokurova S, Wentzensen N, Bastert G, von Knebel Doeberitz M. DNA aneuploidy and integration of human papillomavirus type 16 e6/e7 oncogenes in intraepithelial neoplasia and invasive squamous cell carcinoma of the cervix uteri. Clin Cancer Res 2004;10:3059-63.

93. Häfner N, Driesch C, Gajda M, Jansen L, Kirchmayr R, Runnebaum IB, Dürst M. Integration of the HPV16 genome does not invariably result in high levels of viral oncogene transcripts. Oncogene 2008;27:1610-7.

94. Paavonen J, Jenkins D, Bosch FX, Naud P, Salmerón J, Wheeler CM, Chow SN, Apter DL, Kitchener HC, Castellsague X, de Carvalho NS, Skinner SR, Harper DM, Hedrick JA, Jaisamrarn U, Limson GA, Dionne M, Quint W, Spiessens B, Peeters P, Struyf F, Wieting SL, Lehtinen MO, Dubin G; HPV PATRICIA study group. Efficacy of a prophylactic adjuvanted bivalent L1 virus-like-particle vaccine against infection with human papillomavirus types 16 and 18 in young women: an interim analysis of a phase III double-blind, randomised controlled trial. Lancet 2007;369:301-14.

95. Paavonen J, Naud P, Salmerón J, Wheeler CM, Chow SN, Apter D, Kitchener H, Castellsague X, Teixeira JC, Skinner SR, Hedrick J, Jaisamrarn U, Limson G, Garland S, Szarewski A, Romanowski B, Aoki FY, Schwarz TF, Poppe WA, Bosch FX, Jenkins D, Hardt K, Zahaf T, Descamps D, Struyf F, Lehtinen M, Dubin G; HPV PATRICIA Study Group. Efficacy of human papillomavirus (HPV)-16/18 AS04-adjuvanted vaccine against cervical infection and precancer caused by oncogenic HPV types (PATRICIA): final analysis of a double-blind, randomised study in young women. Lancet 2009;374:301-14.

96. Szarewski A, Poppe WA, Skinner SR, Wheeler CM, Paavonen J, Naud P, Salmeron J, Chow SN, Apter D, Kitchener H, Castellsagué X, Teixeira JC, Hedrick J, Jaisamrarn U, Limson G, Garland S, Romanowski B, Aoki FY, Schwarz TF, Bosch FX, Harper DM, Hardt K, Zahaf T, Descamps D, Struyf F, Lehtinen M, Dubin G; HPV PATRICIA Study Group. Efficacy of the human papillomavirus (HPV)-16/18 AS04-adjuvanted vaccine in women aged 15-25 years with and without serological evidence of previous exposure to HPV16/18. Int J Cancer 2012;131:106-16.

97. Quint W, Jenkins D, Molijn A, Struijk L, van de Sandt M, Doorbar J, Mols J, Van Hoof C, Hardt K, Struyf F, Colau B. One virus one lesion - Individual components of CIN lesions contain a specific HPV type. J Pathol 2012;227:449-65

98. Gariglio P, Gutiérrez J, Cortés E, Vázquez J. The role of retinoid deficiency and estrogens as cofactors in cervical cancer. Arch Med Res 2009;40:449-65.

99. Ding DC, Chiang MH, Lai HC, Hsiung CA, Hsieh CY, Chu TY. Methylation of the long control region of HPV16 is related to the severity of cervical neoplasia. Eur J Obstet Gynecol Reprod Biol 2009; 147:215-29.

100. van de Nieuwenhof HP, Massuger LF, van der Avoort IA, Bekkers RL, Casparie M, Abma W, van Kempen LC, de Hullu JA. Vulvar squamous cell carcinoma development after diagnosis of VIN increases with age. Eur J Cancer 2009;45:851-6.

101. Wright TC Jr, Massad LS, Dunton CJ, Spitzer M, Wilkinson EJ, Solomon D; 2006 American Society for Colposcopy and Cervical Pathology-sponsored Consensus Conference. 2006 consensus 
guidelines for the management of women with abnormal cervical cancer screening tests. Am J Obstet Gynecol 2007;197:346-55.

102. Ambrosio MR, Onorati M, Rocca BJ, Santopietro R. Vulvar cancer and HPV infection: analysis of 22 cases. Pathologica 2008;100:405-7.

103. Gormley RH, Kovarik CL. Human papillomavirus-related genital disease in the immunocompromised host: Part I. J Am Acad Dermatol 2012;66:867.e1-14; quiz 881-2.

104. Bosch FX, Broker TR, Forman D, Moscicki AB, Gillison ML, Doorbar J, Stern PL, Stanley M, Arbyn M, Poljak M, Cuzick J, Castle PE, Schiller JT, Markowitz LE, Fisher WA, Canfell K, Denny LA, Franco EL, Steben M, Kane MA, Schiffman M, Meijer CJ, Sankaranarayanan R, Castellsagué X, Kim JJ, Brotons M, Alemany L, Albero G, Diaz M, de Sanjosé S; authors of ICO Monograph Comprehensive Control of HPV Infections and Related Diseases Vaccine Volume 30, Supplement 5, 2012. Comprehensive control of human papillomavirus infections and related diseases. Vaccine 2013;31 Suppl 7:H1-31.

105. Antonsson A, Spurr TP, Chen AC, Francis GD, McMillan NA, Saunders NA, Law M, Bennett IC. High prevalence of human papillomaviruses in fresh frozen breast cancer samples. $J$ Med Virol 2011;83:2157-63.

106. Khan NA, Castillo A, Koriyama C, Kijima Y, Umekita Y, Ohi Y, Higashi M, Sagara Y, Yoshinaka H, Tsuji T, Natsugoe S, Douchi T, Eizuru Y, Akiba S. Human papillomavirus detected in female breast carcinomas in Japan. Br J Cancer 2008;99:408-14.

107. Kroupis C, Markou A, Vourlidis N, Dionyssiou-Asteriou A, Lianidou ES. Presence of high-risk human papillomavirus sequences in breast cancer tissues and association with histopathological characteristics. Clin Biochem 2006;39:727-31.

108. Lawson JS, WH Gunzburg, NJ Whitaker. Viruses and human breast cancer. Future Microbiol 2006;1:33-51.

109. Frega A, Lorenzon L, Bononi M, De Cesare A, Ciardi A, Lombardi D, Assorgi C, Gentile M, Moscarini M, Torrisi MR, French D. Evaluation of E6 and E7 mRNA expression in HPV DNA positive breast cancer. Eur J Gynaecol Oncol 2012;33:164-7.

110. Jemal A, Bray F, Center MM, Ferlay J, Ward E, Forman D. Global cancer statistics. CA Cancer J Clin 2011;61:69-90.

111. Chaturvedi AK, Engels EA, Pfeiffer RM, Hernandez BY, Xiao W, Kim E, Jiang B, Goodman MT, Sibug-Saber M, Cozen W, Liu L, Lynch CF, Wentzensen N, Jordan RC, Altekruse S, Anderson WF, Rosenberg PS, Gillison ML. Human papillomavirus and rising oropharyngeal cancer incidence in the United States. $J$ Clin Oncol 2011;29:4294-301.

112. Arbyn M, de Sanjosé S, Saraiya M, Sideri M, Palefsky J, Lacey C, Gillison M, Bruni L, Ronco G, Wentzensen N, Brotherton J, Qiao YL, Denny L, Bornstein J, Abramowitz L, Giuliano A, Tommasino M, Monsonego J. EUROGIN 2011 roadmap on prevention and treatment of HPV-related disease. Int J Cancer 2012;131:1969-82.

113. Leemans CR, BJ Braakhuis, RH Brakenhoff. The molecular biology of head and neck cancer. Nat Rev Cancer 2010;11:9-22.

114. Psychogios G, Alexiou C, Agaimy A, Brunner K, Koch M, Mantsopoulos K, Tomppert A, Iro H. Epidemiology and survival of HPV-related tonsillar carcinoma. Cancer Med 2014;3:652-9.

115. van Seters M, van Beurden M, ten Kate FJ, Beckmann I, Ewing PC, Eijkemans MJ, Kagie MJ, Meijer CJ, Aaronson NK, Kleinjan A, Heijmans-Antonissen C, Zijlstra FJ, Burger MP, Helmerhorst TJ. Treatment of vulvar intraepithelial neoplasia with topical imiquimod. N Engl J Med 2008;358:1465-73.

116. Fakhry C, Westra WH, Li S, Cmelak A, Ridge JA, Pinto H, Forastiere A, Gillison ML. Improved survival of patients with human papillomavirus-positive head and neck squamous cell carcinoma in a prospective clinical trial. J Natl Cancer Inst 2008;100:261-9.

117. Schache AG, Liloglou T, Risk JM, Filia A, Jones TM, Sheard J, Woolgar JA, Helliwell TR, Triantafyllou A, Robinson M, Sloan P, Harvey-Woodworth C, Sisson D, Shaw RJ. Evaluation of human papilloma virus diagnostic testing in oropharyngeal squamous cell carcinoma: sensitivity, specificity, and prognostic discrimination. Clin Cancer Res 2011;17:6262-71.

118. Brown LM, Check DP, Devesa SS. Oropharyngeal cancer incidence trends: diminishing racial disparities. Cancer Causes Control 2011;22:753-63.

119. Morshed K. Association between human papillomavirus infection and laryngeal squamous cell carcinoma. J Med Virol 2010;82:1017-23.

120. Rodrigo JP, Hermsen MA, Fresno MF, Brakenhoff RH, GarcíaVelasco F, Snijders PJ, Heideman DA, García-Pedrero JM. Prevalence of human papillomavirus in laryngeal and hypopharyngeal squamous cell carcinomas in northern Spain. Cancer Epidemiol 2015;39:37-41.

121. Hernandez BY, Goodman MT, Lynch CF, Cozen W, Unger ER, Steinau M, Thompson T, Saber MS, Altekruse SF, Lyu C, Saraiya M; HPV Typing of Cancer Workgroup. Human papillomavirus prevalence in invasive laryngeal cancer in the United States. PLoS One 2014;9:e115931.

122. Syrjänen S, Lodi G, von Bültzingslöwen I, Aliko A, Arduino P, Campisi G, Challacombe S, Ficarra G, Flaitz C, Zhou HM, Maeda H, Miller C, Jontell M. Human papillomaviruses in oral carcinoma and oral potentially malignant disorders: a systematic review. Oral Dis 2011;17 Suppl 1:58-72.

123. H Nielsen, B Norrild, P Vedtofte, F Prætorius, J Reibel, P Holmstrup. Human papillomavirus in oral premalignant lesions. Eur J Cancer B Oral Oncol 1996;32B:264-70.

124. Szarka K, Tar I, Fehér E, Gáll T, Kis A, Tóth ED, Boda R, Márton I, Gergely L. Progressive increase of human papillomavirus carriage rates in potentially malignant and malignant oral disorders with increasing malignant potential. Oral Microbiol Immunol 2009;24:314-8.

125. Welters MJ, Kenter GG, Piersma SJ, Vloon AP, Löwik MJ, Berendsvan der Meer DM, Drijfhout JW, Valentijn AR, Wafelman AR, Oostendorp J, Fleuren GJ, Offringa R, Melief CJ, van der Burg SH. Induction of tumor-specific CD4+ and CD8+ T-cell immunity in cervical cancer patients by a human papillomavirus type 16 E6 and E7 long peptides vaccine. Clin Cancer Res 2008;14:178-87.

126. Tseng CW, Hung CF, Alvarez RD, Trimble C, Huh WK, Kim D, Chuang CM, Lin CT, Tsai YC, He L, Monie A, Wu TC. Pretreatment with cisplatin enhances E7-specific CD8+ T-Cell-mediated antitumor immunity induced by DNA vaccination. Clin Cancer Res 2008;14:3185-92.

127. Tseng CW, Trimble C, Zeng Q, Monie A, Alvarez RD, Huh WK, Hoory T, Wang MC, Hung CF, Wu TC. Low-dose radiation enhances therapeutic HPV DNA vaccination in tumor-bearing hosts. Cancer Immunol Immunother 2009;58:737-48.

128. Haas AR, Sun J, Vachani A, Wallace AF, Silverberg M, Kapoor V, Albelda SM. Cycloxygenase-2 inhibition augments the efficacy of a cancer vaccine. Clin Cancer Res 2006;12:214-22.

129. Chaturvedi AK, Engels EA, Anderson WF, Gillison ML. Incidence trends for human papillomavirus-related and -unrelated oral squamous cell carcinomas in the United States. J Clin Oncol 2008;26:612-9.

130. Hammarstedt L, Lindquist D, Dahlstrand H, Romanitan M, Dahlgren LO, Joneberg J, Creson N, Lindholm J, Ye W, Dalianis T, MunckWikland E. Human papillomavirus as a risk factor for the increase in incidence of tonsillar cancer. Int J Cancer 2006;119:2620-3.

131. Marur S, D'Souza G, Westra WH, Forastiere AA. HPV-associated head and neck cancer: a virus-related cancer epidemic. Lancet Oncol 2010;11:781-9.

132. Krüger M, Pabst AM, Walter C, Sagheb K, Günther C, Blatt S, Weise $\mathrm{K}$, Al-Nawas B, Ziebart T. The prevalence of human papilloma virus (HPV) infections in oral squamous cell carcinomas: a retrospective analysis of 88 patients and literature overview. J Craniomaxillofac Surg 2014;42:1506-14.

133. Ruzevick J, Olivi A, Westra WH. Metastatic squamous cell carcinoma to the brain: an unrecognized pattern of distant spread in patients with 
HPV-related head and neck cancer. J Neurooncol 2013;112:449-54.

134. Wood ME, Kelly K, Mullineaux LG, Bunn PA Jr. The inherited nature of lung cancer: a pilot study. Lung Cancer 2000;30:135-44.

135. Matakidou A, Eisen T, Houlston RS. TP53 polymorphisms and lung cancer risk: a systematic review and meta-analysis. Mutagenesis 2003; 18:377-85.

136. Syrjänen K. Papillomavirus infections and cancer Papillomaviruses and Human Disease, ed. K Syrjänen, L Gissmann, LG Koss. 1987, Heidelberg: Springer-Verlag.

137. Syrjänen KJ. Epithelial lesions suggestive of a condylomatous origin found closely associated with invasive bronchial squamous cell carcinomas. Respiration 1980;40:150-60.

138. Trillo A, Guha A. Solitary condylomatous papillomas of the bronchus. Arch Pathol Lab Med 1988;112:731-3.

139. Stremlau A, Gissmann L, Ikenberg H, Stark M, Bannasch P, zur Hausen H. Human papillomavirus type 16 related DNA in an anaplastic carcinoma of the lung. Cancer 1985;55:1737-40.

140. Byrne JC, Tsao MS, Fraser RS, Howley PM. Human papillomavirus-11 DNA in a patient with chronic laryngotracheobronchial papillomatosis and metastatic squamous-cell carcinoma of the lung. $N$ Engl $J$ Med 1987;317:873-8.

141. Syrjanen KJ. HPV infections and lung cancer. J Clin Pathol 2002;55:885-91

142. Gorgoulis VG, Zacharatos P, Kotsinas A, Kyroudi A, Rassidakis AN, Ikonomopoulos JA, Barbatis C, Herrington CS, Kittas C. Human papillomavirus (HPV) is possibly involved in laryngeal but not in lung carcinogenesis. Human Pathol 1999;30:274-83.

143. Rezazadeh A, Laber DA, Ghim SJ, Jenson AB, Kloecker G. The role of human papilloma virus in lung cancer: a review of the evidence. Am J Med Sci 2009;338:64-7.

144. Storey R, Joh J, Kwon A, Jenson AB, Ghim SJ, Kloecker GH. Detection of Immunoglobulin G against E7 of Human Papillomavirus in Non-Small-Cell Lung Cancer. J Oncol 2013;2013:240164.

145. Isa SI, Kurahara Y, Yamamoto S, Tamiya A, Omachi N, Asami K, Okishio K, Utsumi T, Ito N, Yoon HE, Matsumura A, Atagi S, Kawaguchi T. Molecular analysis of human papillomavirus in neversmokers with non-small cell lung cancer. Oncol Lett 2015;9:927-9.

146. Ragin C, Obikoya-Malomo M, Kim S, Chen Z, Flores-Obando R, Gibbs D, Koriyama C, Aguayo F, Koshiol J, Caporaso NE, Carpagnano GE, Ciotti M, Dosaka-Akita H, Fukayama M, Goto A, Spandidos DA, Gorgoulis V, Heideman DA, van Boerdonk RA, Hiroshima K, Iwakawa R, Kastrinakis NG, Kinoshita I, Akiba S, Landi MT, Eugene Liu H, Wang JL, Mehra R, Khuri FR, Lim WT, Owonikoko TK, Ramalingam S, Sarchianaki E, Syrjanen K, Tsao MS, Sykes J, Hee SW, Yokota J, Zaravinos A, Taioli E. HPV-associated lung cancers: an international pooled analysis. Carcinogenesis 2014;35:1267-75.

147. Zhai K, Ding J, Shi HZ. HPV and lung cancer risk: a meta-analysis. J Clin Virol 2015;63C:84-90.

148. Hsueh PR. Human papillomavirus, genital warts, and vaccines. $J$ Microbiol Immunol Infect 2009;42:101-6.

149. Derkay CS. Task force on recurrent respiratory papillomas. A preliminary report. Arch Otolaryngol Head Neck Surg 1995;121:1386-91.

150. Omland T, Lie KA, Akre H, Sandlie LE, Jebsen P, Sandvik L, Nymoen DA, Bzhalava D, Dillner J, Brøndbo K. Recurrent respiratory papillomatosis: HPV genotypes and risk of high-grade laryngeal neoplasia. PLoS One 2014;9:e99114.

151. Major T, Szarka K, Sziklai I, Gergely L, Czeglédy J. The characteristics of human papillomavirus DNA in head and neck cancers and papillomas. J Clin Pathol 2005;58:51-5.

152. Bharti AH, Chotaliya K, Marfatia YS. An update on oral human papillomavirus infection. Indian J Sex Transm Dis 2013;34:77-82.

153. Gallagher TQ, Derkay CS. Pharmacotherapy of recurrent respiratory papillomatosis: an expert opinion. Expert Opin Pharmacother 2009; 10:645-55
154. Kitamura T, Yogo Y, Ueki T, Murakami S, Aso Y. Presence of human papillomavirus type 16 genome in bladder carcinoma in situ of a patient with mild immunodeficiency. Cancer Res 1988;48:7207-11.

155. Gutiérrez J, Jiménez A, de Dios Luna J, Soto MJ, Sorlózano A. Metaanalysis of studies analyzing the relationship between bladder cancer and infection by human papillomavirus. J Urol 2006;176:2474-81.

156. Griffiths TR, Mellon JK. Human papillomavirus and urological tumours: II. Role in bladder, prostate, renal and testicular cancer. $B J U$ Int 2000;85:211-7.

157. Youshya S, Purdie K, Breuer J, Proby C, Sheaf MT, Oliver RT, Baithun S. Does human papillomavirus play a role in the development of bladder transitional cell carcinoma? A comparison of PCR and immunohistochemical analysis. J Clin Pathol 2005;58:207-10.

158. Lopez-Beltran A, Escudero AL, Vicioso L, Muñoz E, Carrasco JC. Human papillomavirus DNA as a factor determining the survival of bladder cancer patients. Br J Cancer 1996;73:124-7.

159. Sano T, Sakurai S, Fukuda T, Nakajima T. Unsuccessful effort to detect human papillomavirus DNA in urinary bladder cancers by the polymerase chain reaction and in situ hybridization. Pathol Int 1995;45:506-12.

160. Li N, Yang L, Zhang Y, Zhao P, Zheng T, Dai M. Human papillomavirus infection and bladder cancer risk: a meta-analysis. $J$ Infect Dis 2011;204:217-23.

161. Jimenez-Pacheco A, Exposito-Ruiz M, Arrabal-Polo MA, LopezLuque AJ. Meta-analysis of studies analyzing the role of human papillomavirus in the development of bladder carcinoma. Korean $J$ Urol 2012;53:240-7.

162. Tenti P, Zappatore R, Romagnoli S, Civardi E, Giunta P, Scelsi R, Stella G, Carnevali L. p53 overexpression and human papillomavirus infection in transitional cell carcinoma of the urinary bladder: correlation with histological parameters. J Pathol 1996;178:65-70.

163. Shigehara K, Sasagawa T, Kawaguchi S, Nakashima T, Shimamura M, Maeda Y, Konaka H, Mizokami A, Koh E, Namiki M. Etiologic role of human papillomavirus infection in bladder carcinoma. Cancer 2011;117:2067-76.

164. Moonen PM, Bakkers JM, Kiemeney LA, Schalken JA, Melchers WJ, Witjes JA. Human papilloma virus DNA and p53 mutation analysis on bladder washes in relation to clinical outcome of bladder cancer. Eur Urol 2007;52:464-8.

165. Kamel D, Pääkkö P, Pöllänen R, Vähäkangas K, Lehto VP, Soini Y. Human papillomavirus DNA and abnormal p53 expression in carcinoma of the urinary bladder. APMIS 1995;103:331-8.

166. Steinestel J, Cronauer MV, Müller J, Al Ghazal A, Skowronek P, Arndt A, Kraft K, Schrader M, Schrader AJ, Steinestel K. Overexpression of p16(INK4a) in urothelial carcinoma in situ is a marker for MAPKmediated epithelial-mesenchymal transition but is not related to human papillomavirus infection. PLoS One 2013;8:e65189.

167. Kim SH, Joung JY, Chung J, Park WS, Lee KH, Seo HK. Detection of human papillomavirus infection and p16 immunohistochemistry expression in bladder cancer with squamous differentiation. PLoS One 2014;9:e93525.

168. Shigehara K, Sasagawa T, Doorbar J, Kawaguchi S, Kobori Y, Nakashima T, Shimamura M, Maeda Y, Miyagi T, Kitagawa Y, Kadono Y, Konaka H, Mizokami A, Koh E, Namiki M. Etiological role of human papillomavirus infection for inverted papilloma of the bladder. J Med Virol 2011;83:277-85.

169. Shaker OG, Hammam OA, Wishahi MM. Is there a correlation between HPV and urinary bladder carcinoma? Biomed Pharmacother 2013;67:183-91

170. Alexander RE, Davidson DD, Lopez-Beltran A, Montironi R, MacLennan GT, Compérat E, Idrees MT, Emerson RE, Cheng L. Human papillomavirus is not an etiologic agent of urothelial inverted papillomas. Am J Surg Pathol 2013;37:1223-8.

171. Alexander RE, Davidson DD, Lopez-Beltran A, Montironi R, MacLennan GT, Compérat E, Idrees MT, Emerson RE, Cheng L. The 
expression patterns of p53 and p16 and an analysis of a possible role of HPV in primary adenocarcinoma of the urinary bladder. PLoS One 2014;9:e95724.

172. Badawi H, Ahmed H, Ismail A, Diab M, Moubarak M, Badawy A, Saber M. Role of human papillomavirus types 16, 18, and 52 in recurrent cystitis and urinary bladder cancer among Egyptian patients. Medscape J Med 2008;10:232

173. Nakashima K, Shigehara K, Kawaguchi S, Wakatsuki A, Kobori Y, Nakashima K, Ishii Y, Shimamura M, Sasagawa T, Kitagawa Y, Mizokami A, Namiki M. Prevalence of human papillomavirus infection in the oropharynx and urine among sexually active men: a comparative study of infection by papillomavirus and other organisms, including Neisseria gonorrhoeae, Chlamydia trachomatis, Mycoplasma spp., and Ureaplasma spp. BMC Infect Dis 2014;14:43.

174. Barghi MR, Rahjoo T, Borghei M, Hosseini-Moghaddam SM, Amani D, Farrokhi B. Association between the evidence of human papilloma virus infection in bladder transitional cell carcinoma in men and cervical dysplasia in their spouses. Arch Iran Med 2012;15:572-4.

175. Berrada N, Al-Bouzidi A, Ameur A, Abbar M, El-Mzibri M, Ameziane-El-Hassani R, Benbacer L, Khyatti M, Qmichou Z, Amzazi S, Attaleb M. Human papillomavirus detection in Moroccan patients with bladder cancer. J Infect Dev Ctries 2013;7:586-92.

176. Castellsagué X, Bosch FX, Muñoz N, Meijer CJ, Shah KV, de Sanjose S, Eluf-Neto J, Ngelangel CA, Chichareon S, Smith JS, Herrero R, Moreno V, Franceschi S; International Agency for Research on Cancer Multicenter Cervical Cancer Study Group. Male circumcision, penile human papillomavirus infection, and cervical cancer in female partners. $N$ Engl J Med 2002;346:1105-12.

177. Bezerra SM, Chaux A, Ball MW, Faraj SF, Munari E, GonzalezRoibon N, Sharma R, Bivalacqua TJ, Burnett AL, Netto GJ. Human papillomavirus infection and immunohistochemical p16 expression as predictors of outcome in penile squamous cell carcinomas. Hum Pathol 2015;46:532-40

178. Lohneis P, Boral S, Kaufmann AM, Lehmann A, Schewe C, Dietel M, Anagnostopoulos I, Jöhrens K. Human papilloma virus status of penile squamous cell carcinoma is associated with differences in tumour-infiltrating T lymphocytes. Virchows Arch 2015;466:323-31.

179. Rubin MA, Kleter B, Zhou M, Ayala G, Cubilla AL, Quint WG, Pirog EC. Detection and typing of human papillomavirus DNA in penile carcinoma: evidence for multiple independent pathways of penile carcinogenesis. Am J Pathol 2001;159:1211-8.

180. Giuliano AR, Nielson CM, Flores R, Dunne EF, Abrahamsen M, Papenfuss MR, Markowitz LE, Smith D, Harris RB. The optimal anatomic sites for sampling heterosexual men for human papillomavirus (HPV) detection: the HPV detection in men study. $J$ Infect Dis 2007;196:1146-52.

181. Schwartz RA, Janniger CK. Bowenoid papulosis. J Am Acad Dermatol 1991;24:261-4.

182. Chao MW, Gibbs P. Squamous cell carcinoma arising in a giant condyloma acuminatum (Buschke-Lowenstein tumour). Asian J Surg 2005;28:238-40

183. Handisurya A, Rieger A, Bago-Horvath Z, Schellenbacher C, Bankier A, Salat A, Stingl G, Kirnbauer R. Rapid progression of an anal Buschke-Lowenstein tumour into a metastasising squamous cell carcinoma in an HIV-infected patient. Sex Transm Infect 2009;85:261-3.

184. Daling JR, Sherman KJ. Relationship between human papillomavirus infection and tumours of anogenital sites other than the cervix. IARC Sci Publ 1992;(119):223-41.

185. Forslund O, Iftner T, Andersson K, Lindelof B, Hradil E, Nordin P, Stenquist B, Kirnbauer R, Dillner J, de Villiers EM; Viraskin Study Group. Cutaneous human papillomaviruses found in sun-exposed skin: Beta-papillomavirus species 2 predominates in squamous cell carcinoma. J Infect Dis 2007;196:876-83.

186. Tschandl P, Rosendahl C, Kittler H. Cutaneous human papillomavirus infection: manifestations and diagnosis. Curr Probl Dermatol 2014;45:92-7.

187. Cobb MW. Human papillomavirus infection. J Am Acad Dermatol 1990;22:547-66.

188. Wallace NA, Robinson K, Howie HL, Galloway DA. HPV 5 and 8 E6 abrogate ATR activity resulting in increased persistence of UVB induced DNA damage. PLoS Pathog 2012;8:e1002807.

189. Iftner T, Elbel M, Schopp B, Hiller T, Loizou JI, Caldecott KW, Stubenrauch F. Interference of papillomavirus E6 protein with single-strand break repair by interaction with XRCC1. EMBO J 2002;21:4741-8.

190. Iftner A, Klug SJ, Garbe C, Blum A, Stancu A, Wilczynski SP, Iftner T. The prevalence of human papillomavirus genotypes in nonmelanoma skin cancers of nonimmunosuppressed individuals identifies high-risk genital types as possible risk factors. Cancer Res 2003;63:7515-9

191. Andersson K, Waterboer T, Kirnbauer R, Slupetzky K, Iftner T, de Villiers EM, Forslund O, Pawlita M, Dillner J. Seroreactivity to cutaneous human papillomaviruses among patients with nonmelanoma skin cancer or benign skin lesions. Cancer Epidemiol Biomarkers Prev 2008;17:189-95.

192. Scarbrough Lefebvre CD, Van Kriekinge G, Gonçalves MA, de Sanjose S. Appraisal of the burden of genital warts from a healthcare and individual patient perspective. Public Health 2011;125:464-75.

193. Grce M, Husnjak K, Skerlev M, Lipozencić J, Pavelić K. Detection and typing of human papillomaviruses by means of polymerase chain reaction and fragment length polymorphism in male genital lesions. Anticancer Res 2000;20:2097-102.

194. Bhatia N, Lynde C, Vender R, Bourcier M. Understanding genital warts: epidemiology, pathogenesis, and burden of disease of human papillomavirus. J Cutan Med Surg 2013;17 Suppl 2:S47-54.

195. Ling MR. Therapy of genital human papillomavirus infections. Part I: Indications for and justification of therapy. Int $J$ Dermatol 1992;31:682-6.

196. Lacey CJ, Lowndes CM, Shah KV. Chapter 4: Burden and management of non-cancerous HPV-related conditions: HPV-6/11 disease. Vaccine 2006;24 Suppl 3:S3/35-41.

197. Ljubojevic S, M Skerlev. HPV-associated diseases. Clin Dermatol 2014;32:227-34

198. Fathi R, Tsoukas MM. Genital warts and other HPV infections: established and novel therapies. Clin Dermatol 2014;32:299-306.

199. Gnanamony M, Peedicayil A, Abraham P. An overview of human papillomaviruses and current vaccine strategies. Indian $J$ Med Microbiol 2007;25:10-7.

200. Remy-Ziller C, Germain C, Spindler A, Hoffmann C, Silvestre N, Rooke R, Bonnefoy JY, Préville X. Immunological characterization of a modified vaccinia virus Ankara vector expressing the human papillomavirus 16 E1 protein. Clin Vaccine Immunol 2014;21:147-55. 